Research Article

\title{
Patterns of Biomass and Carbon Allocation across Chronosequence of Chir Pine (Pinus roxburghii) Forest in Pakistan: Inventory-Based Estimate
}

\author{
Muhammad Amir (D), ${ }^{1}$ Xiaodong Liu $\mathbb{D}^{1},{ }^{1}$ Adnan Ahmad, ${ }^{2}$ Sajjad Saeed, ${ }^{2}$ Abdul Mannan, ${ }^{3}$ \\ and Muhammad Atif Muneer ${ }^{2}$ \\ ${ }^{1}$ Beijing Key Laboratory of Forest Resources and Ecosystem Process, College of Forestry, Beijing Forestry University, \\ 100083 Beijing, China \\ ${ }^{2}$ College of Forestry, Beijing Forestry University, 100083 Beijing, China \\ ${ }^{3}$ Beijing Key Laboratory of Precision Forestry, Beijing Forestry University, 100083 Beijing, China
}

Correspondence should be addressed to Xiaodong Liu; xd_liu@bjfu.edu.cn

Received 28 May 2018; Revised 28 July 2018; Accepted 14 August 2018; Published 18 September 2018

Academic Editor: Anthony R. Lupo

Copyright (c) 2018 Muhammad Amir et al. This is an open access article distributed under the Creative Commons Attribution License, which permits unrestricted use, distribution, and reproduction in any medium, provided the original work is properly cited.

\begin{abstract}
The quantitative relationship between carbon sequestration potential and stand ages of Pine (Pinus roxburghii) forest is not documented in Pakistan. Using field inventory data, this study underlines the patterns of biomass and carbon allocation across a chronosequence of Chir Pine forest. Based on the uniform shelterwood silvicultural management system, the forest was classified into three stand age classes representing the young stand ( $<50$ years), mature stand ( $50-75$ years), and overmature stand ( $>75$ years). The results showed an increasing trend in living tree biomass carbon with stand age. However, soil carbon showed gradually decreasing trend from young to overmature stand. Similarly, deadwood, litter, and understory biomass carbon showed an increase pattern of changes. Altogether, the results highlighted that the mean carbon values of all components varied between $90.3 \mathrm{t} \cdot \mathrm{C} \cdot \mathrm{ha}^{-1}$ in the young stand and $309.5 \mathrm{t} \cdot \mathrm{C} \cdot \mathrm{ha}^{-1}$ in the overmature stand. Furthermore, our results confirm that the current management operations affect the forest floor and soil carbon. Therefore, we suggest that different protection measures should be considered during management operations to enhance soil and forest floor carbon.
\end{abstract}

\section{Introduction}

Biomass and carbon storage in any forest ecosystem play a multiple and significant role in the global carbon cycle [1]. Forest ecosystems have more potential of storing carbon than another terrestrial ecosystem [2]. In a forest, carbon is stored in different pools, but tree and soil are the main components that store more carbon than other components [2-5]. In order to enhance the global carbon sequestration and to increase carbon-absorbing capacity, reforestation, afforestation, and the preservation of existing forest have been suggested as an effective way for mitigation of elevated $\mathrm{CO}_{2}$ concentrations [6-8]. The contribution of forest carbon storage in total carbon of terrestrial ecosystem is significantly important. Generally, forest stand development has a strong relationship with carbon pools of forest ecosystem because tree growth rate of forest ecosystem mostly varies with stand age $[8,9]$. Trees increase their biomass as well as enhance growth by absorbing $\mathrm{CO}_{2}$ from the atmosphere and sequester it in different tree components [10]. As biomass increases, the growth of tree species also increases [11]. Carbon sequestration of a forest depends on forest type, forest stand age, and dominant tree species [11]. Previous studies showed that forest stand age may have a significant effect on the carbon stock among different ecosystem components [12].

Stand age is an important factor affecting storage of carbon in a forest in various components such as in a tree, 
understory, deadwood, and soil $[6,13,14]$ and a strong predictor of the structure and function of a forest ecosystem which may affect the carbon density among carbon pools [15]. Furthermore, various carbon pools of a forest respond differently to stand age [16]. Therefore, it is important to understand the relationship of stand age with different carbon components and sequestration rate [17]. A number of studies underline the effect of stand age on carbon allocation among different carbon banks $[6,7,18]$. The biomass carbon of living trees increases with an increase in stand age $[19,20]$. However, this increasing trend followed a sigmoidal trend, as young trees carbon grow rapidly up to a certain age and then gradually decline [21].

In Pakistan, the researchers mainly focused on the measurement of forest carbon in the subtropical forest [22], temperate forest [23-25], and in the planted forest [26]. However, no up-to-date studies have been carried out on the carbon allocation with respect to stand age. In addition, biomass carbon measurement is based on already available inventory data in which the minimum diameter is selected from $10 \mathrm{~cm}$ to $16 \mathrm{~cm}$ in various forests types of Pakistan, which may underestimate the available carbon storage and sequestration rate [22]. In order to assess the carbon allocation among different carbon pools in relation to stand age, the present study was conducted in subtropical Chir forest. Pinus roxburghii is the dominant species of subtropical Chir zone in Pakistan. It is widely distributed in the Murree Hill including Dir, Swat, and Azad Kashmir. Large plantations have been raised in Mansehra and Abbottabad areas of KPK. It is mostly found in the form of monospecific community. This species is easily cultivated and naturally regenerated in the northern area of Punjab and KPK province and considered as fast-growing and valuable species for forestation and reforestation of denuded areas of Pakistan [27].

Subtropical Chir Pine forest is managed under shelterwood management system. Under this system, the area of the forest is divided into different blocks on the base of age carrying with different management operations. Cutting and felling operations are concentrated to overmature blocks, thinning operation are carried out in mature block, and cleaning operations are in the young block. These management operations in various blocks may affect the carbon allocation in different carbon pools particularly in the litter, deadwood, and soil. Thus, complete accurate information is needed regarding biomass and carbon storage in different age stand of the Chir with respect to the current management operations. Therefore, we designed this study with overall objectives of assessing biomass and carbon stock of $P$. roxburghii forest ecosystem on basis of stand age and outlining the effect of management practices on carbon stock in respective stand age classes.

\section{Materials and Methods}

2.1. Study Area. The study was carried out in Murree Hill of Pakistan. The latitude and longitude of the study area range from $33^{\circ} 47^{\prime} 15^{\prime \prime}$ to $33^{\circ} 54^{\prime} 47^{\prime \prime} \mathrm{N}$ and from $73^{\circ} 16^{\prime} 54^{\prime \prime}$ to $73^{\circ}$ $29^{\prime} 18^{\prime \prime}$ E. The elevations from sea level range from 939 to $1873 \mathrm{~m}$. The average precipitation varies from 500 to
$1200 \mathrm{~mm}$ while temperature ranges from $-5^{\circ} \mathrm{C}$ in winter to $40^{\circ} \mathrm{C}$ in summer in the study area. The rocks are sedimentary in origin and comprise of shales, sandstones, limestone, and marls. The soil is loamy in nature with a variable proportion of sand, silt, and clay [27]. The study site is the natural zone of Chir forest that is managed under shelterwood system. The dominant tree species of the area is Chir Pine (PR). The major associated tree species are Pinus wallichiana (kail), Quercus incana (rhin), and Pyrus pashia (batangi). The associated understory flora includes Myrsine africana (khukhal), Berberis lycium spp. (sumblu), Carissa spinarum (granda), Dodonaea viscosa (sanatha), Adhatoda vasica (Bahekar), Capparis decidua (karir), and cannabis sativa (Bang) (Figure 1).

\subsection{Description of Shelterwood System and Research Design.} Based on the uniform shelterwood silvicultural system, the forest area is divided into four periodic blocks (PBI, PBII, PBIII, and PBIV) on the base of rotation age (100 years) and regeneration period (25 years), thus forming four age stands that are (1-25, 26-50, 51-75, and 76-100 years). Under this system, the first in the mature crop (PBIV), a regeneration felling, is carried out in which all the trees are not felled, but prescribed numbers of trees (seed bearers) are retained over the area for seed production. Mostly, 10-20 trees $\cdot \mathrm{ha}^{-1}$ are retained for the seed production. When the regeneration is established, then the final felling is carried out to remove the seed bearers for the development of the new crop. The regeneration and final felling are completed in 25 years. In PBIII, the thinning operations are carried out with the object to enhance the growth and to prepare the crop for felling. Thinning is mostly concentrated in the lower diameter classes. In PBII, and PBI thinning and cleaning operations are carried out. A theoretical sketch of the system is given in Table 1.

Because of the same management operations in PBI and PBII, we placed these two periodic blocks into young age class (1-50 years). Similarly, PBIII represents the mature stand (50-75 years) and PBIV represents overmature stand (>75 years). In each block, sample plots were selected randomly for data collection. The size of each sample plot size was $20 \mathrm{~m} \times 30 \mathrm{~m}$. In each plot, tree diameter $(\mathrm{cm})$ and height $(\mathrm{m})$ along with stem density $\left(\mathrm{ha}^{-1}\right)$ were measured. In each sample plot of the respective block, subplots of $1 \mathrm{~m}^{2}$ were laid out for soil samples collection. Similarly, samples were also collected from these subplots for the litter, deadwood, and understory carbon analysis.

2.2. Biomass Inventory. Tree volume was determined from tree basal area, tree height, and form factor (Equation (1)) [28]. The value of form factor was sourced from the literature [29]. From tree volume $\left(\mathrm{m}^{3} \cdot \mathrm{ha}^{-1}\right)$ and basic wood density $\left(\mathrm{kg} \mathrm{m}^{3}\right)$, stem biomass was calculated (Equation (2)). The basic wood density (BWD) value was obtained from the available literature [30]. The total (above and below ground) biomass $\left(\mathrm{t} \cdot \mathrm{ha}^{-1}\right)$ was obtained from stem biomass $\left(\mathrm{m}^{3} \cdot \mathrm{ha}^{-1}\right)$, biomass expansion factor (BEF), and root to shoot ration (R) following IPCC (2006) guidelines (Equation (3)). 


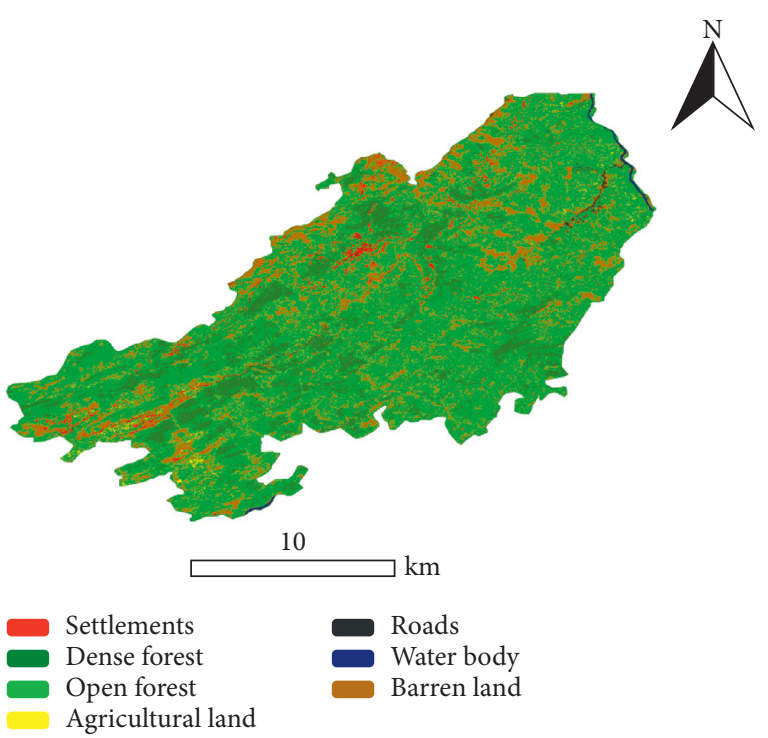

Figure 1: Study area: Muree Hill, Punjab, Pakistan.

TABLE 1: Theoretical sketch of the system.

\begin{tabular}{lcc}
\hline $\begin{array}{l}\text { Periodic } \\
\text { blocks }\end{array}$ & $\begin{array}{c}\text { Age at the time } \\
\text { of formation }\end{array}$ & $\begin{array}{c}\text { Age at the end of regeneration } \\
\text { period }\end{array}$ \\
\hline PBI & $1-25$ & $77-100$ \\
PBII & $26-50$ & $51-70$ \\
PBIII & $51-71$ & $26-50$ \\
PBIV & $76-100$ & $1-25$ \\
\hline
\end{tabular}

The $\mathrm{BEF}$ and $\mathrm{R}$ values were obtained from the literature $[22,26,30-32]$. The whole relations are as follows:

$$
\text { tree volume }\left(\mathrm{m}^{3} \cdot \mathrm{ha}^{-1}\right)=\frac{\pi}{4} \times D^{2} \times H \times F,
$$

where $\mathrm{BA}=$ basal area $\left(\mathrm{m}^{2} \cdot \mathrm{ha}^{-1}\right), H=$ total tree height $(\mathrm{m})$, and $F=$ form factor. The value of FF was sourced from the previous literature $[26,29]$ :

$$
\begin{aligned}
\operatorname{stem} \text { biomass }\left(\mathrm{t} \cdot \mathrm{ha}^{-1}\right)= & \text { basic wood density }\left(\mathrm{kg} / \mathrm{m}^{3}\right) \\
& \times \operatorname{volume}\left(\mathrm{m}^{3}\right),
\end{aligned}
$$

total biomass $\left(\mathrm{t} \cdot \mathrm{ha}^{-1}\right)=$ stem biomass $\left(\mathrm{t} \cdot \mathrm{ha}^{-1}\right) \times \mathrm{BEF} \times R$.

For the biomass estimation of herbs, the vegetation was destructively harvested. Similarly, the deadwood and litter were also collected within $1 \mathrm{~m}^{2}$ subplots following $[22-26,33]$. The fresh weight of all samples was recorded, and then one Kg subsample was transferred to the laboratory and dried at $72^{\circ} \mathrm{C}$ for 48 hours for biomass measurement and then extrapolated to the contemporary weight of the whole plot [34-36]:

$$
\operatorname{Biomass}\left(\mathrm{t} \cdot \mathrm{ha}^{-1}\right)=\frac{\mathrm{WS}}{\mathrm{A}} \times \frac{\mathrm{WDS}}{\mathrm{WFS}} \times \frac{1}{10,000},
$$

where WS= weight of wet field sample in gram (g), WDS = weight of dry subsample in gram (g), WFS = weight of fresh dry subsample in Gram (g), and A = area in hectare (ha).

2.3. Carbon Stocks Assessment. The carbon stocks values in trees, herbs, and deadwood were calculated from biomass using a conversion factor having value 0.5 (Equation (5)) [22, 23, 34-37]:

$$
\text { carbon stock }\left(\mathrm{t} \cdot \mathrm{ha}^{-1}\right)=\operatorname{biomass}\left(\mathrm{t} \cdot \mathrm{ha}^{-1}\right) \times 0.5 \text {. }
$$

The carbon stocks values in litter were calculated from biomass using a conversion factor having value 0.47 (Equation (6)) following IPCC (2006) guidelines:

$$
\text { carbon stock }\left(\mathrm{t} \cdot \mathrm{ha}^{-1}\right)=\operatorname{biomass}\left(\mathrm{t} \cdot \mathrm{ha}^{-1}\right) \times 0.47 \text {. }
$$

2.4. Soil Organic Carbon. For the estimation of soil carbon stock, soil samples were taken with soil auger at the depth of $0-15 \mathrm{~cm}$ and $16-30 \mathrm{~cm}$ in each plot. The weight of each sample was measured in the field, and the samples were put in labeled bags and were brought to the laboratory for further analysis. The soil bulk density $\left(\mathrm{g} \cdot \mathrm{cm}^{3}\right)$ of each sample was measured from the weight of soil sample and volume of the core. Soil carbon content was measured following the procedure of Walkley and Black method [38], and soil carbon in $\mathrm{t} \cdot \mathrm{ha} \mathrm{a}^{-1}$ was calculated from the following equation $[22,23,39]$ :

$$
\begin{aligned}
\operatorname{soil} \text { carbon }\left(\mathrm{t} \cdot \mathrm{ha}^{-1}\right)= & \mathrm{SBD}\left(\mathrm{g} / \mathrm{cm}^{3}\right) \times \operatorname{SOC}(\%) \\
& \times \operatorname{SHT}(\mathrm{cm}) \times 100
\end{aligned}
$$

where SBK = soil bulk density $\left(\mathrm{g} / \mathrm{cm}^{3}\right), \mathrm{SOC}=$ soil organic content $(\%)$, and SHT = soil horizon thickness $(\mathrm{cm})$.

2.5. Statistical Analysis. Statistical software (sigma plot 12.5) was used for the manipulation of statistical data. Regression models were developed for the relationship between diameter $(\mathrm{cm})$ and tree height $(\mathrm{m})$, basal area $\left(\mathrm{m}^{2} \cdot \mathrm{ha}^{-1}\right)$, and volume $\left(\mathrm{m}^{3} \cdot \mathrm{ha}^{-1}\right)$, biomass $\left(\mathrm{t} \cdot \mathrm{ha}^{-1}\right)$ and carbon stocks $\left(\mathrm{t} \cdot \mathrm{ha}^{-1}\right)$. One-way ANOVA (all pairwise comparison) was applied to test the significance of the means values.

\section{Results}

3.1. Growing Stock and Biomass. The results revealed that the average stem density ranged from $636 \pm 93.7$ (trees.ha ${ }^{-1}$ ) in the young stand to $147 \pm 56.7$ (trees ha ${ }^{-1}$ ) in the overmature stand. A statistical higher stem density was found in the young stand while lower stem density was found in the overmature stand. The basal area in young, mature, and overmature stands was $15.51 \pm 1.6\left(\mathrm{~m}^{2} \cdot \mathrm{ha}^{-1}\right), 35.57 \pm 18.0$ $\left(\mathrm{m}^{2} \cdot \mathrm{ha}^{-1}\right)$, and $45.91 \pm 15.1\left(\mathrm{~m}^{2} \cdot \mathrm{ha}^{-1}\right)$, respectively. Statistically, no significant variation was found in the mature and overmature stand in the basal area; however, young stand showed significantly lowest basal area. The highest total volume was found in the overmature stand, while lowest volume was recorded in the young stand (Table 2). Further regression analysis between basal area and volume showed a significant relationship among all stands (Table 3). The characteristics of growing stock are figured in Table 2. 
TABle 2: Growing stock characteristics of Chir Pine forest.

\begin{tabular}{lccccc}
\hline Age group & Mean DBH $(\mathrm{cm})$ & Mean height $(\mathrm{m})$ & Mean basal area $\left(\mathrm{m}^{2} \cdot \mathrm{ha}^{-1}\right)$ & Mean stand density $\left(\right.$ trees ha $\left.^{-1}\right)$ & $\begin{array}{c}\text { Mean stand volume } \\
\left(\mathrm{m}^{3} \cdot \mathrm{ha}^{-1}\right)\end{array}$ \\
\hline Young & $17.4 \pm 1.5$ & $9.6 \pm 1.8$ & $15.5 \pm 1.6^{\mathrm{B}}$ & $636.6 \pm 93.7^{\mathrm{A}}>$ & $83.0 \pm 12.9^{\mathrm{C}}$ \\
Mature & $41 \pm 5.9$ & $18.9 \pm 4.2$ & $35.5 \pm 18.0^{\mathrm{A}}$ & $267 \pm 115.7^{\mathrm{B}}$ & $356.0 \pm 105.9^{\mathrm{B}}$ \\
Overmature & $63.8 \pm 11.5$ & $19.7 \pm 5.7$ & $45.9 \pm 15.1^{\mathrm{A}}$ & $147.6 \pm 56.7^{\mathrm{C}}$ & $549.4 \pm 107.1^{\mathrm{A}}$ \\
Mean & 40.7 & 16.0 & 32.3 & 350.4 & 329.4 \\
\hline
\end{tabular}

Superscripts in each column show significant differences at $\alpha=0.1$ and $p \leq 0.0001$.

TABLE 3: Relationship type, equation, and $R^{2}$ value of the Pinus roxburghii stands.

\begin{tabular}{|c|c|c|c|c|}
\hline Age class & Parameters & Relationship type & Equation & $R^{2}$ value \\
\hline Young stand & $\begin{array}{c}\text { BA \& V } \\
\text { BA \& STBM } \\
\text { BA \& TBM } \\
\text { BA \& TCS } \\
\text { D \& H }\end{array}$ & $\begin{array}{l}\text { Polynomial, quadratic } \\
\text { Polynomial, quadratic } \\
\text { Polynomial, quadratic } \\
\text { Polynomial, quadratic } \\
\text { Polynomial, quadratic }\end{array}$ & $\begin{array}{l}f=-0.07+3.53 * x+0.86 * x^{2} \\
f=-0.04+2.15 * x+0.52 * x^{2} \\
f=-0.07+3.25 * x+0.80 * x^{2} \\
f=-0.03+1.62 * x+0.40 * x^{2} \\
f=-4.22+0.90 * x+-0.00 * x^{2}\end{array}$ & $\begin{array}{l}0.94 \\
0.94 \\
0.94 \\
0.94 \\
0.99\end{array}$ \\
\hline Mature stand & $\begin{array}{c}\text { BA \& V } \\
\text { BA \& STBM } \\
\text { BA \& TBM } \\
\text { BA \& TCS } \\
\text { D \& H }\end{array}$ & $\begin{array}{l}\text { Polynomial, quadratic } \\
\text { Polynomial, quadratic } \\
\text { Polynomial, quadratic } \\
\text { Polynomial, quadratic } \\
\text { Polynomial, quadratic }\end{array}$ & $\begin{array}{c}f=-0.99+10.01 * x+0.09 * x^{2} \\
f=-0.60+6.11 * x+0.05 * x^{2} \\
f=-0.92+9.22 * x+0.08 * x^{2} \\
f=-0.46+4.61 * x+0.04 * x^{2} \\
f=-0.08+0.77 * x-0.00 * x^{2}\end{array}$ & $\begin{array}{l}0.99 \\
0.99 \\
0.99 \\
0.99 \\
0.99\end{array}$ \\
\hline Overmature stand & $\begin{array}{c}\text { BA \& V } \\
\text { BA \& STBM } \\
\text { BA \& TBM } \\
\text { BA \& TCS } \\
\text { D \& H }\end{array}$ & $\begin{array}{l}\text { Polynomial, quadratic } \\
\text { Polynomial, quadratic } \\
\text { Polynomial, quadratic } \\
\text { Polynomial, quadratic } \\
\text { Polynomial, quadratic }\end{array}$ & $\begin{array}{c}f=-0.87+12.93 * x-0.08 * x^{2} \\
f=-0.53+7.88 * x-0.05 * x^{2} \\
f=-0.80+11.91 * x-0.08 * x^{2} \\
f=-0.40+5.95 * x-0.04 * x^{2} \\
f=8.65+0.45 * x-0.00 * x^{2}\end{array}$ & $\begin{array}{l}0.99 \\
0.99 \\
0.99 \\
0.99 \\
0.99\end{array}$ \\
\hline
\end{tabular}

$\mathrm{BA}=$ basal area $\left(\mathrm{m}^{2} \cdot \mathrm{ha}^{-1}\right), \mathrm{V}=$ volume $\left(\mathrm{m}^{3} \cdot \mathrm{ha}^{-1}\right), \mathrm{STBM}=$ stem biomass $\left(\mathrm{t} \cdot \mathrm{ha}^{-1}\right), \mathrm{TBM}=$ total biomass $\left(\mathrm{t} \cdot \mathrm{ha}^{-1}\right), D=$ diameter $(\mathrm{cm})$, and $H=$ height $(\mathrm{m})$.

The total tree biomass distribution of Chir Pine forest of the young, mature, and overmature stand was recorded at $80.0 \pm 12.4\left(\mathrm{t} \cdot \mathrm{ha}^{-1}\right), 343.1 \pm 167.6\left(\mathrm{t} \cdot \mathrm{ha}^{-1}\right)$, and $529.5 \pm 176.8$ $\left(\mathrm{t} \cdot \mathrm{ha}^{-1}\right)$, respectively, demonstrating a rapid increase of biomass from young stand age trees to overmature stand age trees (Table 4). The stem made the largest contribution to total tree biomass. The results of ANOVA showed that the mean value of stem biomass and total tree biomass significantly different among the age classes (Table 4). Moreover, the regression analysis between basal area and biomass revealed strong positive correlation (Table 3, Figure 2). In addition to total tree biomass, we also measured the value of biomass in understory vegetation, deadwood, and litter, and no significant variation was observed among all age classes in their values (Table 4).

3.2. Carbon Stocks. The results show the values of a living tree, understory vegetation, litter, deadwood, and soil carbon of the respective age stands (Table 5). It can be seen from the table that the average living tree carbon varied between $40.0 \pm 6.2\left(\mathrm{t} \cdot \mathrm{ha}^{-1}\right)$ and $264.5 \pm 88.4\left(\mathrm{t} \cdot \mathrm{ha}^{-1}\right)$, respectively. Among the all age stands, significantly larger value was recorded in the overmature stand, whereas smaller value was recorded in the young age stand. The mean value of carbon in understory vegetation was found the maximum in the mature stand. Similarly, deadwood and litter carbon were recorded higher in the overmature stand and lower in the mature stand. However, no significant variation was found in carbon values of understory vegetation, deadwood, and
TABLE 4: Biomass of Chir Pine forest.

\begin{tabular}{lcccc}
\hline Age group & $\begin{array}{c}\text { Mean } \\
\text { STBM } \\
\left(\mathrm{t} \cdot \mathrm{ha}^{-1}\right)\end{array}$ & $\begin{array}{c}\text { Mean } \\
\text { TTBM } \\
\left(\mathrm{t} \cdot \mathrm{ha}^{-1}\right)\end{array}$ & $\begin{array}{c}\text { Mean HLDM } \\
\left(\mathrm{t} \cdot \mathrm{ha}^{-1}\right)\end{array}$ & $\begin{array}{c}\text { Mean TBM } \\
\left(\mathrm{t} \cdot \mathrm{ha}^{-1}\right)\end{array}$ \\
\hline Young & $\begin{array}{c}50.6 \pm \\
7.8^{\mathrm{C}}\end{array}$ & $\begin{array}{c}80.0 \pm \\
12.4^{\mathrm{C}}\end{array}$ & $0.7 \pm 0.3$ & $131.3^{\mathrm{C}}$ \\
Mature & $217.1 \pm$ & $343.1 \pm$ & $0.9 \pm 0.3$ & $561.1^{\mathrm{B}}$ \\
& $125.6^{\mathrm{B}}$ & $167.6^{\mathrm{B}}$ & & \\
Overmature & $335.1 \pm$ & $529.5 \pm$ & $1.0 \pm 1$ & $865.1^{\mathrm{A}}$ \\
Mean & $126.3^{\mathrm{A}}$ & $176.8^{\mathrm{A}}$ & $1.0 \pm 1$ & 519.1 \\
\hline
\end{tabular}

Superscripts in each column show significant differences at $\alpha=0.1$ and $p \leq 0.0001$. STBM $=$ stem biomass; $\quad \mathrm{TTBM}=$ total tree biomass; $\mathrm{HLDM}=$ herb, litter, and deadwood biomass; TBM=total biomass; $\mathrm{TBM}=\mathrm{STBM}+\mathrm{TTBM}+\mathrm{HLDM}$.

litter in all age stands. Soil organic carbon analysis showed that young stand holds the maximum soil carbon and the overmature stand holds minimum carbon. The results showed a decreasing trend from young to overmature stand in soil carbon (see Figure 3).

\section{Discussion}

The present findings showed that stem density of Chir Pine in all age stands decreases with increasing diameter. In Chir Pine forest, not only natural thinning is common, but stem removal under the shelterwood system is also practiced which are mostly concentrated in the mature and overmature age class [22]. Those areas of the forest where 

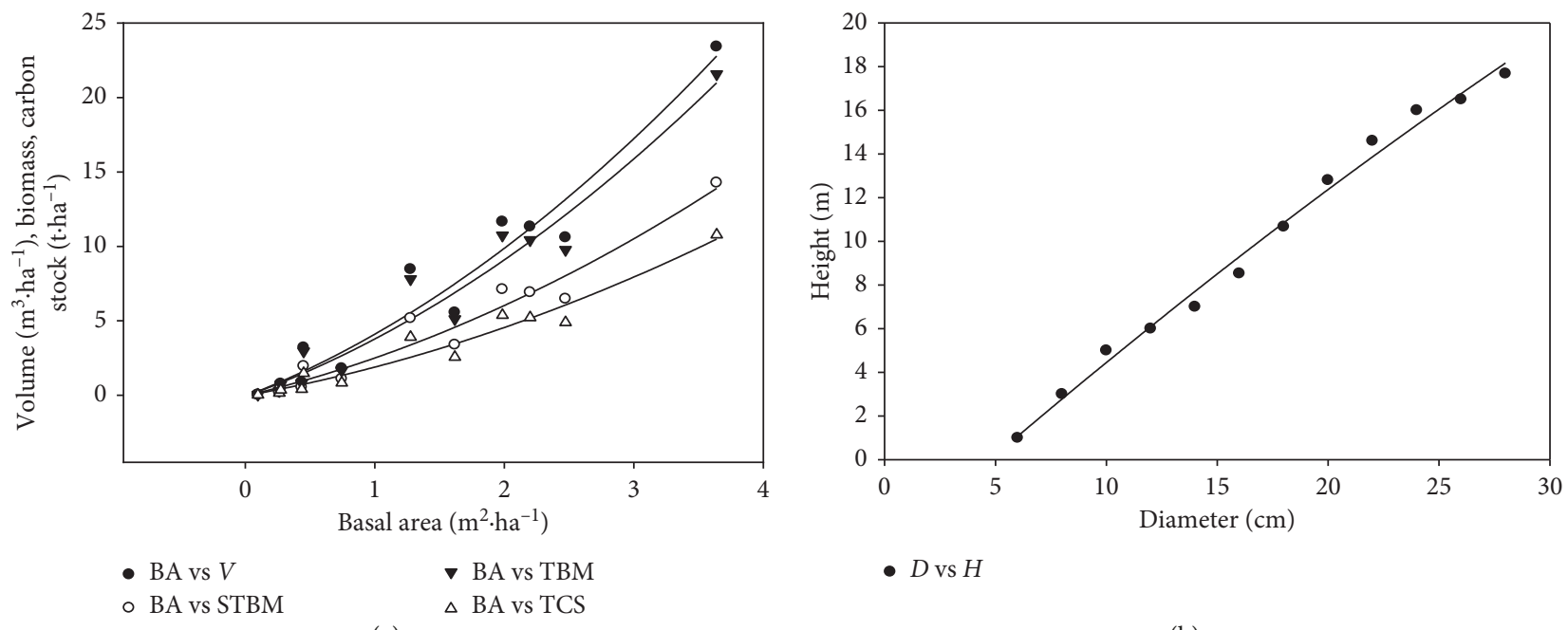

(a)

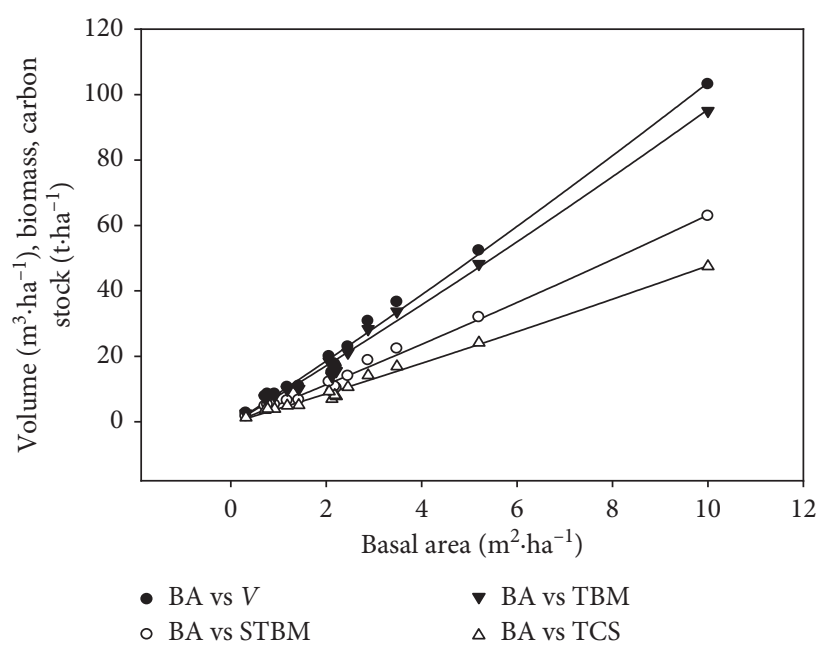

(b)

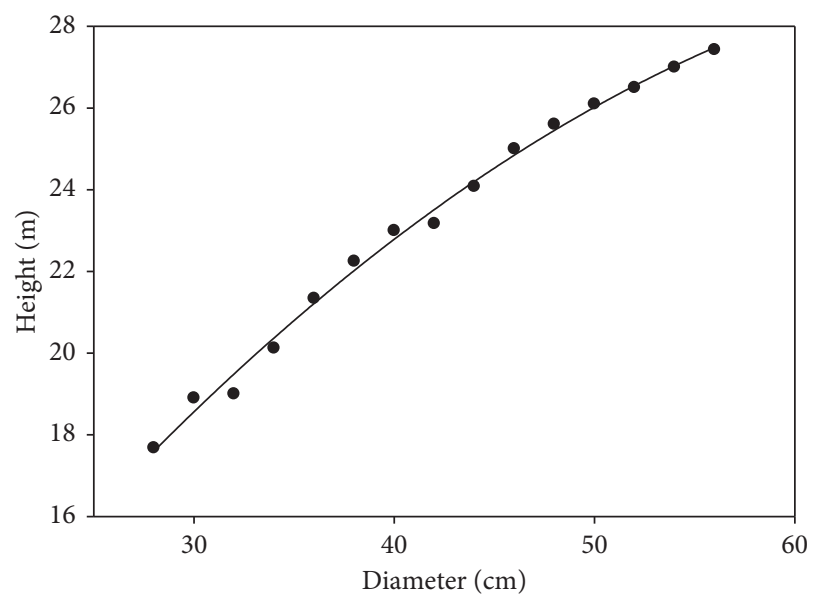

- $D$ vs $H$

(c)

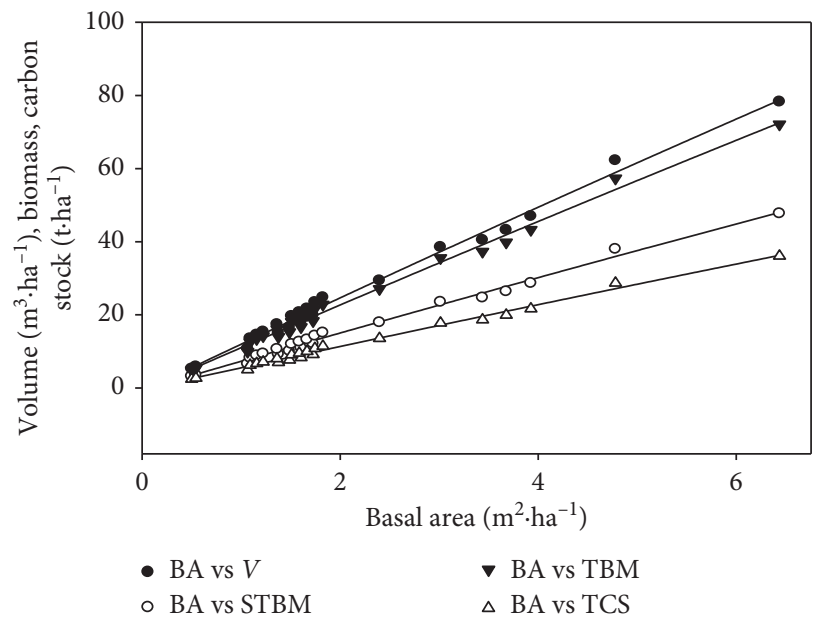

(e)

(d)

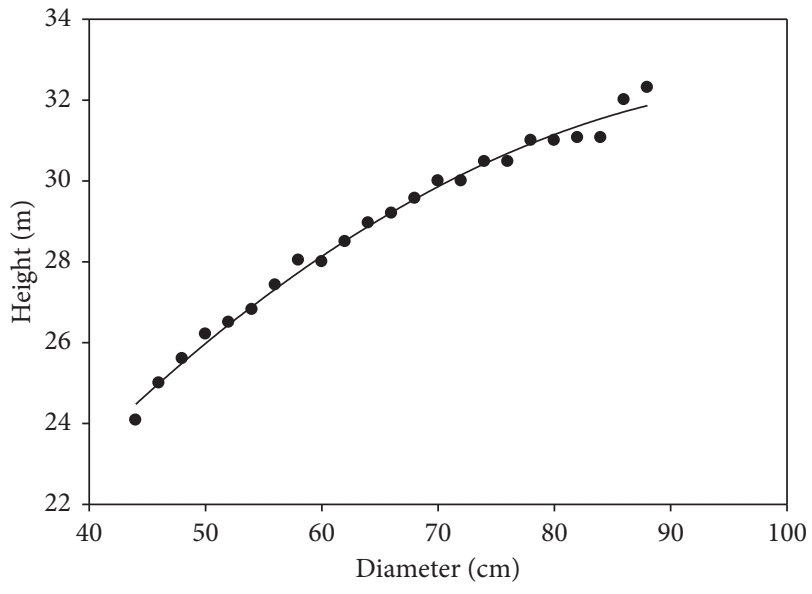

- $D$ vs $H$

(f)

Figure 2: Relationship between $D$ and $H, B A$, and $V$, STBM, TBM, TCS in the young (a, b), mature (c, d), and overmature (e, f). $D=$ diameter $(\mathrm{cm}), H=$ height $(\mathrm{m}), \mathrm{BA}=$ basal area $\left(\mathrm{m}^{2} \cdot \mathrm{ha}^{-1}\right), V=$ volume $\left(\mathrm{m}^{3} \cdot \mathrm{ha}^{-1}\right), \mathrm{STBM}=$ stem biomass $(\mathrm{t} / \mathrm{ha}), \mathrm{TBM}=$ total biomass $(\mathrm{t} / \mathrm{ha}), \mathrm{TCS}=$ total carbon stock $\left(\mathrm{t} \cdot \mathrm{ha}^{-1}\right)$. 
Table 5: Carbon stocks of Chir Pine forest.

\begin{tabular}{lcccc}
\hline Age group & Mean LTC $\left(\mathrm{t} \cdot \mathrm{ha}^{-1}\right)$ & Mean HLD $\left(\mathrm{t} \cdot \mathrm{ha}^{\mathrm{1}}\right)$ & ${\text { Mean SC }\left(\mathrm{t} \cdot \mathrm{ha}^{-1}\right)}$ & ${\text { Mean TC }\left(\mathrm{t} \cdot \mathrm{ha}^{-1}\right)}^{\mathrm{C}}$ \\
\hline Young & $40.0 \pm 6.2^{\mathrm{C}}$ & $0.3 \pm 0.15^{\mathrm{A}}$ & $50.0 \pm 11.8^{\mathrm{A}}$ & $90.3^{\mathrm{C}}$ \\
Mature & $171.5 \pm 83.5^{\mathrm{B}}$ & $0.4 \pm 0.1^{\mathrm{A}}$ & $46.2 \pm 15.7^{\mathrm{A}}$ & $218.1^{\mathrm{B}}$ \\
Over mature & $264.5 \pm 88.4^{\mathrm{A}}$ & $0.4 \pm 0.45^{\mathrm{A}}$ & $44.4 \pm 9.1^{\mathrm{A}}$ & $309.5^{\mathrm{A}}$ \\
Mean & 158.6 & 0.36 & 46.9 & 205.9 \\
\hline
\end{tabular}

Superscripts in each column show significant differences at $\alpha=0.1$ and $p \leq 0.0001$. LTC $=$ living tree carbon; HLDC= herb, litter, and deadwood carbon; $\mathrm{SC}=$ soil carbon; $\mathrm{TC}=$ total carbon; $\mathrm{TC}=\mathrm{LTC}+\mathrm{HLDC}+\mathrm{SC}$.

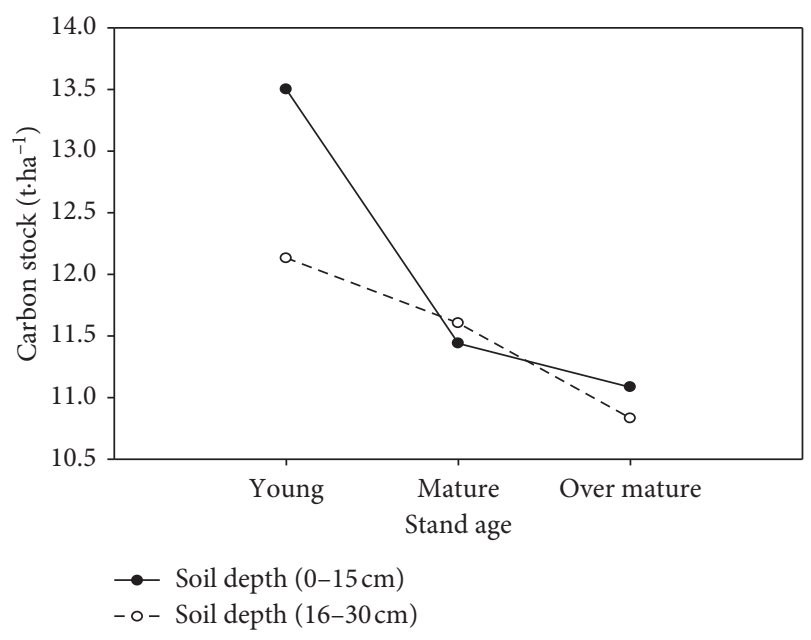

FIGURE 3: Soil carbon stock in young, mature, and overmature stand at $0-15 \mathrm{~cm}$ and $15-30 \mathrm{~cm}$ depth increment.

thinning and felling operations are completed were then allocated to the young age class, and consequently $72 \%$ regeneration potential was recorded in the young stand. This also resulted in lower stem volume and stem biomass in young age class as compared to old age stands. The results further demonstrated that Chir Pine biomass carbon in living tree increased steadily with age stand. These findings are consistent with $[6,19,40,41]$, confirming that stand age is the important variable in biomass carbon estimation. However, the mean values of understory vegetation (USV) and deadwood carbon showed contrasting pattern against the living tree biomass carbon. The USV biomass carbon was recorded higher in the mature stand as compared to young stand and overmature stand. This can be attributed to management operations in the forest. It has been discussed earlier that Chir forest in Pakistan is managed under shelterwood system. Under this system, the young crops received the cleaning, and clearing operations hence resulted in lower biomass carbon values. Similarly, in overmature stand heavy thinning, regeneration felling and final felling operations are carried out that may affect the biomass carbon of USV. In contrast, the mature block receives mostly the thinning and selected felling operations. This creates canopy gaps, thus providing a favorable condition for the growth of USV. Consequently, it gives the larger value of biomass carbon.

The biomass carbon of deadwood was found higher in the overmature block. This higher value of biomass carbon in overmature block reflects the effect of management operations. In the mature block, due to felling operation, the accumulation of more wood materials on forest floor resulted in higher deadwood carbon. The previous results also reported that biomass carbon for conifer chronosequence increases with stand age [42-44], and some researches showed that the carbon stock of forest floor and understory vegetation decreased with increasing stand age $[8,19]$ because of high susceptibility to disturbances, variation, and decomposition rate in stand age $[6,8,45]$. The results of our soil carbon analysis showed decreasing trend with respect to age. This decreasing trend in soil may be attributed to the soil disturbance during the felling operations in the overmature stand and decrease in the natural thinning with the stand age. The soil organic carbon has many limitations that whether or not soil organic carbon stock could change with respect to stand ages [46, 47]. Some previous studies showed that there is no significant increase in soil organic carbon stock with stand age $[46,17]$, while some other previous studies showed increasing of soil organic carbon with increasing stand age $[45,47,48]$. The difference may due to different factors such as climatic factor, soil factor, and forest type [6], but in case of the present study, the lower soil carbon with respect to increasing stand age is the result of management operations such as thinning and felling. During these operations, the soil becomes disturbed and the top layer gets exposed to wind and rainfall that wash out the surface soil, reducing the soil organic matter and soil carbon. However, generally, soil organic carbon increases with stand age in conifer forest, due to the accumulation of organic matter in older stages $[14,40]$.

In conclusion, our results depicted that the biomass carbon of living tree (LT) increases with stand age. However, the value of soil carbon, deadwood, and USV carbon did not follow the same trend. Altogether, our current findings figure out that the mean carbon values of all components varied between $90.3 \mathrm{t} \cdot \mathrm{C} \cdot \mathrm{ha}^{-1}$ in young, $218.1 \mathrm{t} \cdot \mathrm{C} \cdot \mathrm{ha}^{-1}$ in mature, and $309.5 \mathrm{t} \cdot \mathrm{C} \cdot \mathrm{ha}^{-1}$ in the overmature stand. These results indicated the significant increasing trend in carbon stocks with stand age. These present results highlighted the importance of age in assessing carbon measurement of a forest. Furthermore, our results showed the effects of management operations on the forest floor and soil carbon. The lower soil carbon value in the overmature stand is the result of soil disturbances during management operations.

\section{Limitations and Uncertainties}

This study was conducted using the field inventory method to explore patterns of biomass and carbon allocation across Chronosequence of Chir Pine (Pinus roxburghii) forest in Pakistan. We calculate the stem biomass from stem volume 
and wood density and then converted stem biomass to total tree (above ground) biomass using a fixed generic BEF value of 1.51 following Haripriya [30], IPCC [31], and Nizami [22]. For measuring the belowground biomass carbon, we used a root to shoot ration $(R)$ of 0.19 following Rana et al. [32]. As the BEF and $R$ value may vary with stand age, the present estimates of carbon allocation along the Chronosequence may contain some uncertainties, which might induce errors in carbon stock estimation along the stand age.

\section{Data Availability}

The data used to support the findings of this study are available from the corresponding author upon request.

\section{Conflicts of Interest}

The authors declare that they have no conflicts of interest.

\section{Acknowledgments}

The authors would like to thank the National Key Research and Development Project of China (2017YFD0600106), China Scholarship Council (http://www.csc.edu.cn), and Beijing Forestry University (http://www.bjfu.edu.cn) for supporting this study. Moreover, the authors thank Range and Divisional forest officers, Punjab Forest Department, for providing technical support and facilities during forest inventory.

\section{References}

[1] B. K. Acharya, B. Chettri, and L. Vijayan, "Distribution pattern of trees along an elevation gradient of eastern Himalaya, India," Acta Oecologica, vol. 37, no. 4, pp. 329-336, 2011.

[2] R. Houghton, "Balancing the global carbon budget," Annual Review of Earth and Planetary Sciences, vol. 35, no. 1, pp. 313-347, 2007.

[3] S. Brown, "Measuring carbon in forests: current status and future challenges," Environmental Pollution, vol. 116, no. 3, pp. 363-372, 2002.

[4] S. T. Gower, "Patterns and mechanisms of the forest carbon cycle," Annual Review of Environment and Resources, vol. 28, no. 1, pp. 169-204, 2003.

[5] R. Houghton, "Aboveground forest biomass and the global carbon balance," Global Change Biology, vol. 11, no. 6, pp. 945-958, 2005.

[6] M. Peichl and M. A. Arain, "Above-and belowground ecosystem biomass and carbon pools in an age-sequence of temperate pine plantation forests," Agricultural and Forest Meteorology, vol. 140, no. 1, pp. 51-63, 2006.

[7] M. Peichl and M. A. Arain, "Allometry and partitioning of above-and belowground tree biomass in an age-sequence of white pine forests," Forest Ecology and Management, vol. 253, no. 1, pp. 68-80, 2007.

[8] A. R. Taylor, J. R. Wang, and H. Y. Chen, "Carbon storage in a chronosequence of red spruce (Picea rubens) forests in central Nova Scotia, Canada," Canadian Journal of Forest Research, vol. 37, no. 11, pp. 2260-2269, 2007.

[9] B. E. Law, O. Sun, J. Campbell, S. Van Tuyl, and P. E. thornton, "Changes in carbon storage and fluxes in a chronosequence of ponderosa pine," Global Change Biology, vol. 9, no. 4, pp. 510-524, 2003.

[10] E. Matthews, R. Payne, M. Rohweder et al., "Forest ecosystem: carbon storage sequestration, carbon sequestration in soil," Global Climate Change Digest, vol. 12, no. 2, pp. 19-99, 2000.

[11] B. Huy and P. Tuan Ahn, Estimating $\mathrm{CO}_{2}$ Sequestration in Natural Broad-Leaved Evergreen Forests in Vietnam, APANews (FAO), Quebec, Canada, 2008.

[12] K. S. Pregitizer and E. S. Euskirchen, "Carbon cycling and storage in world forests: biome patterns retated to forest age," Global Change Biology, vol. 10, no. 12, pp. 2052-2077, 2004.

[13] J. L. Martin, S. T. Gower, J. Plaut, and B. Holmes, "Carbon pools in a boreal mixedwood logging chronosequence," Global Change Biology, vol. 11, no. 11, pp. 1883-1894, 2005.

[14] A. Zerva, T. Ball, K. A. Smith et al., "Soil carbon dynamics in a Sitka spruce (Picea sitchensis (Bong.) Carr.) chronosequence on a peaty gley," Forest Ecology and Management, vol. 205, no. 1-3, pp. 227-240, 2005.

[15] J. B. Bradford and D. N. Kastendick, "Age-related patterns of forest complexity and carbon storage in pine and aspen-birch ecosystems of northern Minnesota, USA," Canadian Journal of Forest Research, vol. 40, no. 3, pp. 401-409, 2010.

[16] B. Zhu, X. Wang, J. Fang et al., "Altitudinal changes in carbon storage of temperate forests on Mt Changbai, Northeast China," Journal of Plant Research, vol. 123, no. 4, pp. 439-452, 2010.

[17] X. Cheng, H. Han, F. Kang et al., "Variation in biomass and carbon storage by stand age in pine (Pinus tabulaeformis) planted ecosystem in Mt. Taiyue, Shanxi, China," Journal of Plant Interactions, vol. 9, no. 1, pp. 521-528, 2014.

[18] N. J. Noh, Y. Son, S. K. Lee et al., "Carbon and nitrogen storage in an age-sequence of Pinus densiflora stands in Korea," Science China Life Sciences, vol. 53, no. 7, pp. 822-830, 2010.

[19] J. Cao, X. Wang, Y. Tian et al., "Pattern of carbon allocation across three different stages of stand development of a Chinese pine (Pinus tabulaeformis) forest," Ecological Research, vol. 27, no. 5, pp. 883-892, 2012.

[20] B. Tobin and M. Nieuwenhuis, "Biomass expansion factors for Sitka spruce (Picea sitchensis (Bong.) Carr.) in Ireland," European Journal of Forest Research, vol. 126, no. 2, pp. 189-196, 2007.

[21] A. R. Weiskittel, D.W. Hann, J.A. Kershaw Jr. et al., Forest Growth and Yield Modelling, John Wiley \& Sons, Hoboken, NJ, United States, 2011.

[22] S. M. Nizami, "The inventory of the carbon stocks in sub tropical forests of Pakistan for reporting under kyoto protocol," Journal of Forestry Research, vol. 23, no. 3, pp. 377-384, 2012.

[23] A. Ahmad, S. M. Nizami, K. Marwat et al., "Annual accumulation of carbon in the coniferous forest of dir kohistan: an inventory based estimate," Pakistan Journal of Botany, vol. 47, pp. 115-118, 2015.

[24] A. Ahmad and S. M. Nizami, "Carbon stocks of different land uses in the Kumrat valley, Hindu Kush region of Pakistan," Journal of Forestry Research, vol. 26, no. 1, pp. 57-64, 2015.

[25] A. Ahmad, Q. I. J. Liu, S. M. Nizami, A. Mannan, and S. Saeed, "Carbon emission from deforestation, forest degradation and wood harvest in the temperate region of Hindukush Himalaya, Pakistan between 1994 and 2016," Land Use Policy, vol. 78, pp. 781-790, 2018.

[26] S. Saeed, M. I. Ashraf, A. Ahmad et al., "The Bela forest ecosystem of district Jhelum, a potential carbon sink," Pakistan Journal of Botany, vol. 48, no. 1, pp. 121-129, 2016. 
[27] M. 1. Sheikh, Trees of Pakistan, Pictoral Printers, vol. 110, p. 95, Islamabad, Pakistan, 1993.

[28] D. Lu, P. Mausel, E. Brondizio et al., "Classification of successional forest stages in the Brazilian Amazon basin," Forest Ecology and Management, vol. 181, no. 3, pp. 301-312, 2003.

[29] S. Magnussen and D. Reed, Modeling for Estimation and Monitoring, Knowledge Reference for National Forest Assessments, FAO-IUFRO, Quebec, Canada, 2004.

[30] G. Haripriya, "Estimates of biomass in Indian forests," Biomass and Bioenergy, vol. 19, no. 4, pp. 245-258, 2000.

[31] IPCC, Intergovernmental Panel on Climate Change (IPCC) Guidelines for National Greenhouse Gas, IPCC, Geneva, Switzerland, 2006.

[32] B. Rana, S. Singh, and R. Singh, "Biomass and net primary productivity in Central Himalayan forests along an altitudinal gradient," Forest Ecology and Management, vol. 27, no. 3-4, pp. 199-218, 1989.

[33] A. Mannan, Z. Feng, A. Ahmad et al., "Carbon shift with land use change in Margallah Hills National Park, Islamabad (Pakistan), from 1990 to 2017," Applied Ecology and Environment Research, vol. 16, no. 3, pp. 3197-3214, 2018.

[34] G. R. Oliver, S. H. Pearce, J. D. Graham et al., "Carbon in plantation understorey shrubs," Scion Contract Report, vol. 43877, 2009.

[35] Y. Malhi, T. R. Baker, O. L. Phillips et al., "The above-ground coarse wood productivity of 104 neotropical forest plots," Global Change Biology, vol. 10, no. 5, pp. 563-591, 2004.

[36] J. Roy, H. A. Mooney, and B. Saugier, Terrestrial Global Productivity, Elsevier, New york, NY, USA, 2001.

[37] L. Sun and D. S Guan, "Carbon stock of the ecosystem of lower subtropical broadleaved evergreen forests of different ages in pearl river delta, China," Journal of Tropical Forest Science, vol. 26, no. 2, pp. 249-258, 2014.

[38] A. Walkley and I. A. Black, "An examination of the Degtjareff method for determining soil organic matter, and a proposed modification of the chromic acid titration method," Soil Science, vol. 37, no. 1, pp. 29-38, 1934.

[39] T. R. Pearson, S. L. Brown, and R. A. Birdsey, Measurement Guidelines for the Sequestration of Forest Carbon, US Department of Agriculture, Forest Service, Northern Research Station, Washington, D.C., USA, 2007.

[40] C. Li, T. Zha, J. Liu et al., "Carbon and nitrogen distribution across a chronosequence of secondary lacebark pine in China," The Forestry Chronicle, vol. 89, no. 2, pp. 192-198, 2013.

[41] C. M. Litton, J. W. Raich, and M. G. Ryan, "Carbon allocation in forest ecosystems," Global Change Biology, vol. 13, no. 10, pp. 2089-2109, 2007.

[42] J. B. Bradford, R. A. Birdsey, L. A. Joyce et al., "Tree age, disturbance history, and carbon stocks and fluxes in subalpine Rocky Mountain forests," Global Change Biology, vol. 14, no. 12 , pp. 2882-2897, 2008.

[43] R. Joosten, J. Schumacher, C. Wirth et al., "Evaluating tree carbon predictions for beech (Fagus sylvatica L.) in western Germany," Forest Ecology and Management, vol. 189, no. 1-3, pp. 87-96, 2004.

[44] H. Zheng, Z. Ouyang, W. Xu et al., "Variation of carbon storage by different reforestation types in the hilly red soil region of southern China," Forest Ecology and Management, vol. 255, no. 3-4, pp. 1113-1121, 2008.

[45] K. S. Pregitzer and E. S. Euskirchen, "Carbon cycling and storage in world forests: biome patterns related to forest age," Global Change Biology, vol. 10, no. 12, pp. 2052-2077, 2004.
[46] K. A. Farley, E. F. Kelly, and R. G. Hofstede, "Soil organic carbon and water retention after conversion of grasslands to pine plantations in the Ecuadorian Andes," Ecosystems, vol. 7, no. 7, pp. 729-739, 2004.

[47] B. Lemma, D. B. Kleja, I. Nilsson et al., "Soil carbon sequestration under different exotic tree species in the southwestern highlands of Ethiopia," Geoderma, vol. 136, no. 3-4, pp. 886-898, 2006.

[48] T. D. Hookera and J. E. Compton, "Forest ecosystem carbon and nitrogen accumulation during the first century after agricultural abandonment," Ecological Applications, vol. 13, no. 2, pp. 299-313, 2003. 

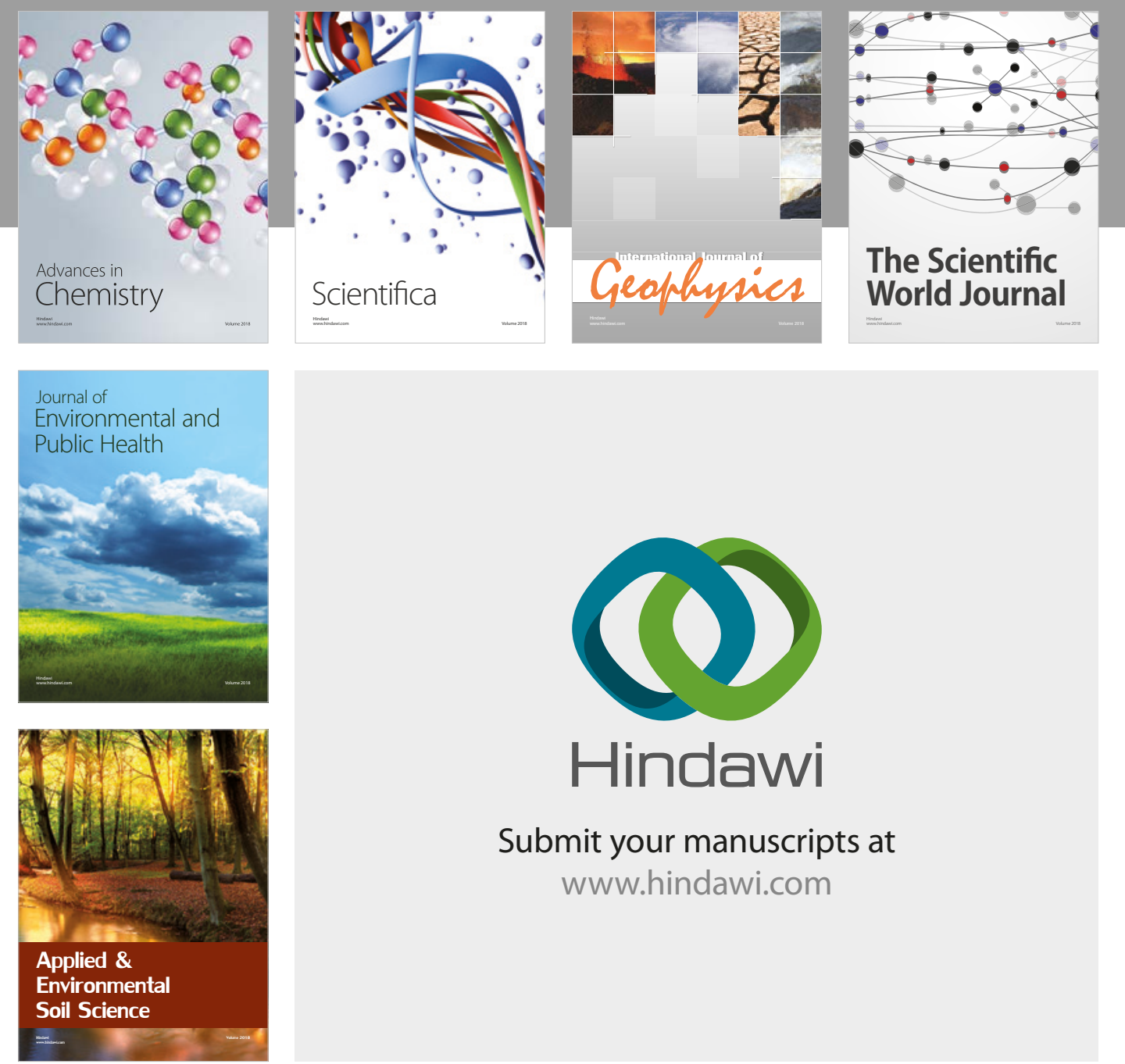

The Scientific

\section{World Journal}
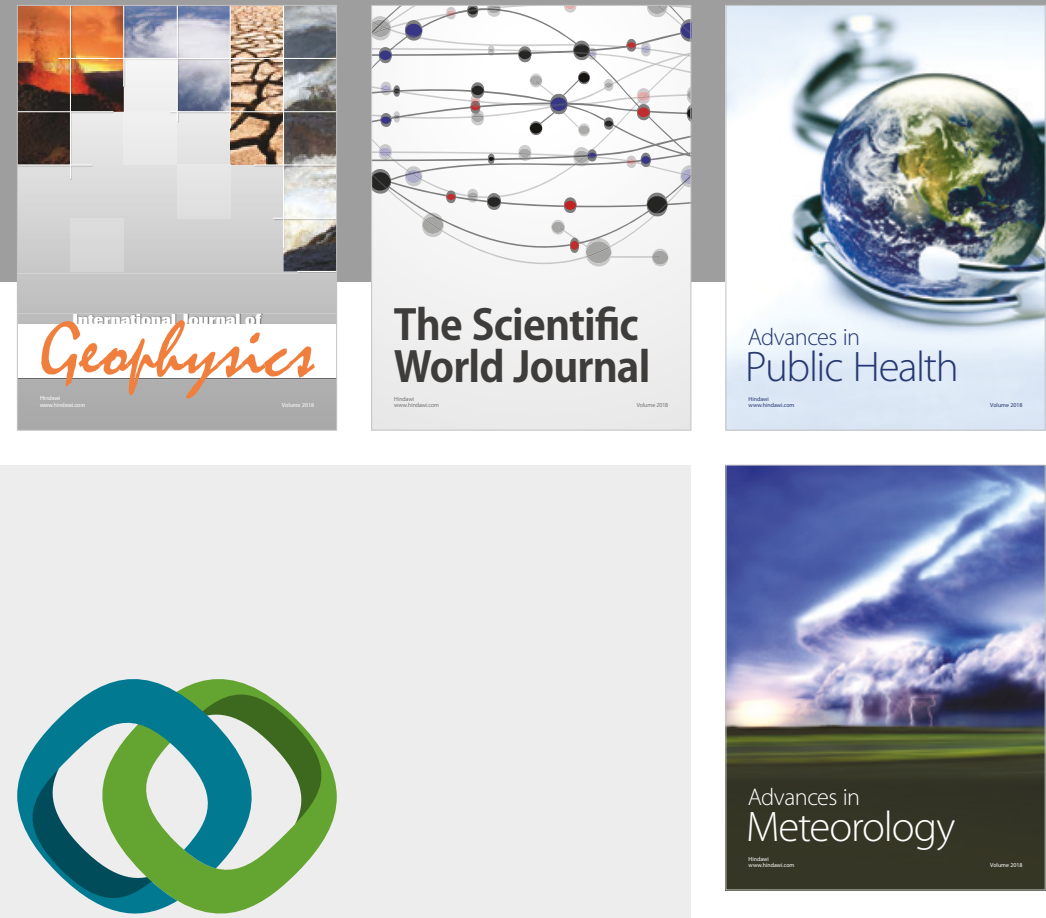

Advan

Public Health

\section{Hindawi}

Submit your manuscripts at

www.hindawi.com
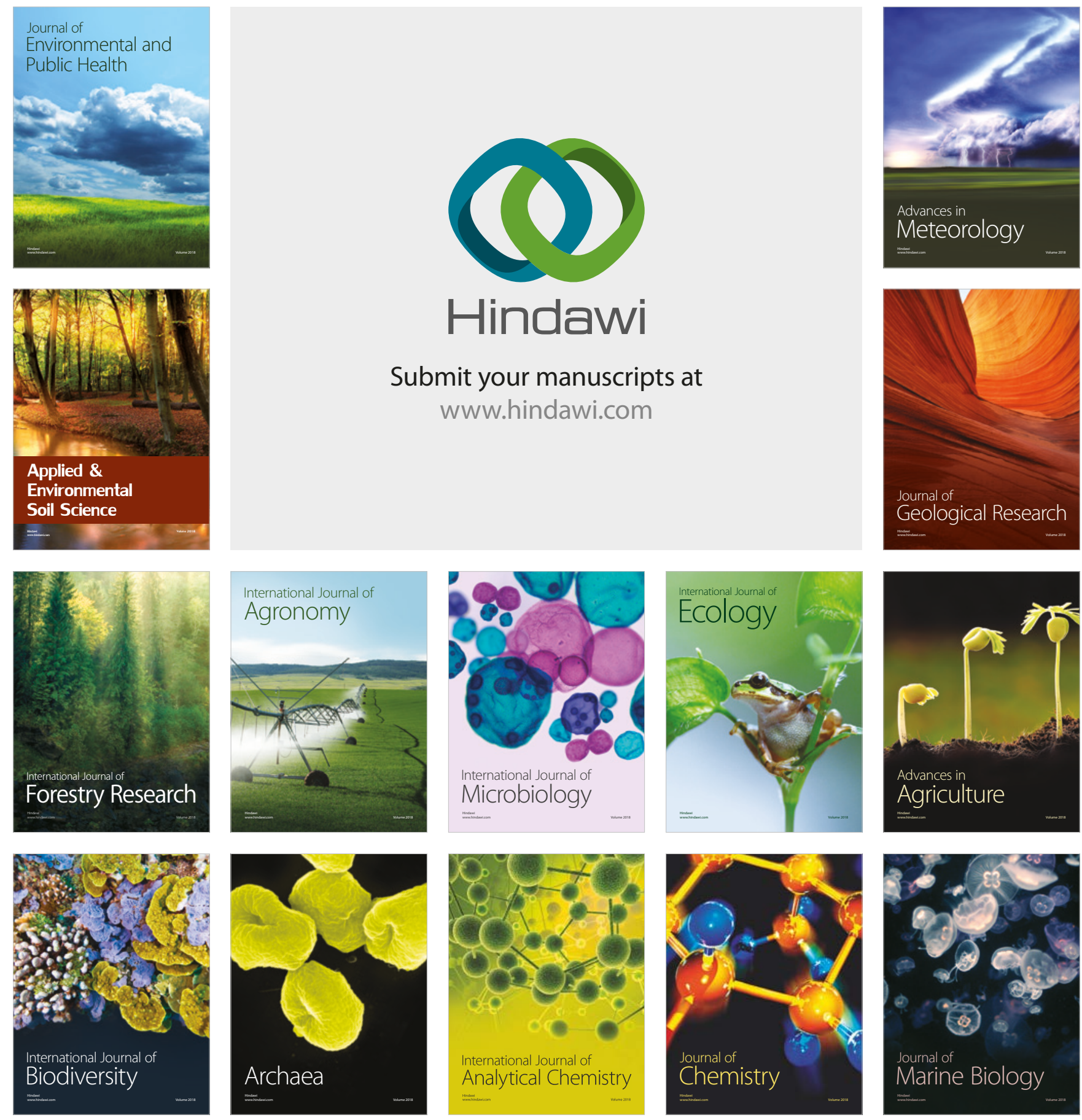